\title{
Analisis Kualitas Udara untuk Monitoring Kesehatan Lingkungan Rumah Sakit
}

\author{
Khodijah Amiroh, Oktavia Ayu Permata, Farah Zakiyah Rahmanti \\ Fakultas Teknologi Informasi dan Industri, Institut Teknologi Telkom Surabaya, Surabaya, Indonesia
}

\section{KEYWORDS}

Air quality, $\mathrm{CO}, \mathrm{CO} 2$, analysis

\section{CORRESPONDENCE}

E-mail: dijaamirah@ittelkom-sby.ac.id

\section{A $\mathbf{B}$ S $\mathbf{T} \mathbf{R}$ A $\mathbf{K}$}

Kualitas udara merupakan faktor penting dalam kesehatan sanitasi rumah sakit.Rumah sakit merupakan instasi pelayanan kesehatan dengan inti kegitan promotive, preventif, kuratif, dan rehabilitative. Gas $\mathrm{CO}$ dan $\mathrm{CO}_{2}$ merupakan salah satu indikator dalam penilaian kesehatan lingkungan sanitasi rumah sakit sesuai dengan Kepmenkes 1204 tahun 2004. Alat monitoring yang dibuat fokus untuk melihat kondisi gas $\mathrm{CO}$ dan $\mathrm{CO}_{2}$ secara real-time. Analisis deskriptif dilakukan dengan menggunakan 10 parameter statistik. Selain analisis deksriptif juga menggunakan analisa histrogram. Hasil pengujian yang dilakukan pada tiga kondisi yakni kamar pasien, area parkir, dan pada ruang tunggu mendapat hasil yang bervariasi. Pada kamar pasien didapatkan hasil kualitas udara yang paling baik. Sedangkan pada area parkir mendapatkan hasil yang paling buruk. Pada area ruang tunggu rumah sakit hasil yang didapatkan kadar $\mathrm{CO}_{2}$ yang buruk. Alat pengukuran berdasarkan hasil kalibrasi mengalami error sebesar $15,11 \%$ untuk sensor $\mathrm{CO}$ dan $24,08 \%$ untuk $24,08 \%$. Hasil pengujian pengiriman informasi dari mikrokontroller ke aplikasi meunjukkan hasil error sebesar 2,3\%.

\section{PENDAHULUAN}

Udara merupakan campuran gas yang terdapat pada permukaan bumi. Pada keadaan kering udara mengandung $78 \%$ nitrogen, $21 \%$ oksigen, dan $1 \%$ uap air, serta karbondioksida dan gas2 lainnya. Pada ketinggian tertentu udara akan memiliki komposisi yang berbeda dan berubah sesuai dengan faktor kondisi tersebut. Kualitas dari udara yang telah berubah komposisinya dari komposisi udara alamiahnya merupakan udara yang sudah tercemar. Udara yang tercemar apabila dalam keadaan yang berbahaya maka tidak dapat menyangga kehidupan. [1]

Rumah sakit merupakan instansi pelayanan kesehatan dengan inti kegiatan promotive, preventif, kuratif, dan rehabilitative. Dampak negative dari kesehatan lingkungan rumah sakit adalah pencemaran lingkungan yang perlu perhatian khusus yang terdapat dari limbah medis dan non medis. Penyehatan lingkungan rumah sakit merupakan kegiatan penunjang yang cukup penting dalam kegiatan pelayanan rumah sakit. Sesuai dengan pedoman Kepmenkes 1204 tahun 2004 tentang persyaratan kesehatan lingkungan rumah sakit, terdapat beberapa pokok pengolahan sanitasi kesehatan lingkungan rumah sakit meliputi penyediaan air bersih, pengolaan makanan, penolaan linen, sanitasi ruangan dan peralatan, serta pengendalian serangga dan tikus. [2]

Kualitas udara baik didalam maupun diluar ruangan memerlukan pemerhatian khusus pada lingkungan rumah sakit karena berpengaruh pada kesehatan manusia. Beberapa pencemaran seperti debu, gas, asap, dan uap selain menjadikan polusi juga akan menyebabkan virus dan bakteri pada udara. [3]. Kematian yang disebabkan oleh pencemaran udara di perkotaan pada daerah berkembang adalah sebesar $9 \%$ dan di daerah perdesaan adalah sebesar 1\% untuk negara berkembang. (Buletin WHO 2000) [4] 
Gas $\mathrm{CO}$ dan $\mathrm{CO}_{2}$ yang ada pada udara apabila melebihi batas dapat menyebababkan racun pada tubuh. Gas $\mathrm{CO}$ dapat membuat seseorang yang memiliki gangguan pernapasan akan menjadi sesak nafas. Hal tersebut dikarenakan oksigen yang seharusnya dialirkan oleh hemoglobin ke seluruh tubuh tidak dapat dialirkan karena hemoglobin yang seharusnya mengikat oksigen dan dialirkan ke seluruh tubuh menjadi mengikat gas $\mathrm{CO}$. Gas $\mathrm{CO}$ pada dasarnya akan lebih mudah diikat oleh hemoglobin dari pada oksigen yang dibutuhkan oleh tubuh. Sedangkan pada seseorang yang mengalami gangguan penapasan apabila terpapar gas $\mathrm{CO}_{2}$ berlebihan akan mengalami pusing dan sesak napas. [5]

Dengan alasan itulah maka dirasa perlu untuk memonitoring suatu kualitas udara dengan memfokuskan pada dua kadar udara yakni $\mathrm{CO}$ dan $\mathrm{CO}_{2}$ pada rumah sakit. $\mathrm{CO}$ dan $\mathrm{CO}_{2}$ merupakan gas yang tidak berbau dan tidak terlihat pada manusia sehingga dibutuhkan alat monitoring khusus untuk memantau kadar gas yang berbahaya secara realtime.

\section{Mekanisme Kerja Sistem}

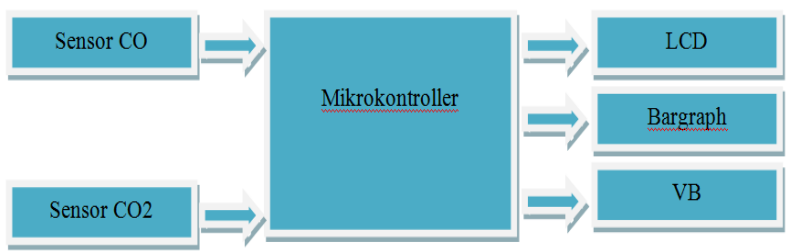

Gambar 1. Blok Diagram Sistem

Sesuai dengan gambar 1 diatas mekanisme kerja sistem alat monitoring ini antara lain adalah dengan menggunakan Sensor Gas Pendeteksi CO dan Sensor Gas Pendekteksi $\mathrm{CO}_{2}$. Sensor gas $\mathrm{CO}$ yang digunakan adalah Sensor MQ-7 dan gas $\mathrm{CO}_{2}$ adalah Sensor MQ-135. Sedangkan mikrokontroller yang digunakan adalah ATMega 128. Output dari hasil monitoring adalah berupa LCD dan Bargraph serta secara serial dengan menggunakan Visual Basic. Analisa dilakukan pada VB dengan melakukan analisis deskriptif dan melakukan korelasi dan regresi data.

\section{Sensor Gas CO dan $\mathrm{CO} 2$}

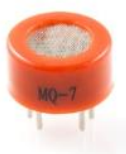

Gambar 2. Sensor Gas MQ-7

Sensor Gas CO yang digunakan adalah Sensor Gas MQ-7 sensor tersebut merupakan sebuah modul sensor yang bereaksi terhadap kadar gas karbon monoksida yang terdapat dalam udara. Pada modul sensor tersebut memiliki output data digital. Modul tersebut juga dapat digunakan sebagai alarm peringatan dini. Sensor gas CO ini juga dilakukan kalibrasi pada laboratorium UPTK3 Surabaya dimana pengujian dilakukan sebanyak 3 kali. Setiap pengambilan data dilakukan selama 15 menit. Dari hasil kalibrasi didapatkan rata-rata error pengambilan data adalah sekitar $15,11 \%$

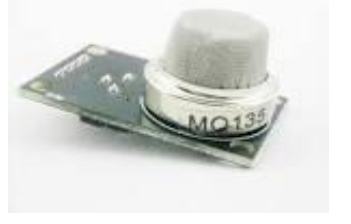

Gambar 3. Sensor Gas MQ-135
Sensor gas $\mathrm{CO}_{2}$ yang digunakan adalah sensor gas MQ-135 dimana sensor tersebut merupakan sensor yang dapat mendeteksi gas ammonia, benzol, alkhol, dioksida, serta gas berbahaya lainnya. Sama seperti sensor gas MQ-7 output pada modul sensor gas ini adalah data digital. Sebelum digunakan untuk pengambilan data, sensor ini juga dilakukan kalibrasi pada laboratorium UPTK3 Surabaya dimana pengunjian dilakukan sebanyak 3 kali. Setiap pengambilan data dilakukan selama 15 menit. Dari hasil kalibrasi didapatkan rata-rata error pada pengambilan data adalah $24,08 \%$.

\section{Analisis Statistik}

Analisis yang dilakukan dalam setelah data diproses adalah dengan analisis deskriptif dan analisis hitrogram. Dengan melakukan analisis deskriptif hasil dari penilitian dapat menggambarkan persoalan dengan cara menata data tersebut sedemikian rupa sehingga dengan mudah dapat dipahami bagaimana karakteristik datanya kemudian dapat dijelasan secara rinci dan berguna untuk keperluan pengambilan kesimpulan selanjutnya. Analisis deskriptif yang dilakukan antara lain adalah dengan menmpilkan data max, min, mean, range, modus, median, varians, skewness, kurtosis, dan standard deviasi.

Sedangkan analisis histogram merupakan distribusi frekuensi yang digunakan untuk mengetahui distribusi data yang telah dikumpulka. Analisis histogram ini dilakukan agar lebih mudah dibaca karena data disajikan dengan berupa histogram batang.

\section{Analisa Korelasi dan Regresi}

Korelasi dan regresi dilakukan karena suatu permasalah penelitian biasanya dapat dijelaskan oleh dua atau lebih variable yang saling berhubungan satu sama lain. Variabel yang saling berhubungan tersebut membentuk suatu persamaan matematis yang biasa disebut dengan persamaan regresi yang dapat digunakan untuk menntukan nilai sebuah variable yang tergantung pada variable yang lain. Namun sebelum melakukan uji regresi lebih dulu dilakukan uji korelasi untuk mengetahui hubungan antara sensor dan referensi bersifat linier atau tidak.

\section{METODOLOGI}

\section{Perancangan Perangkat Keras}

Pada alat monitoring ini perangkat keras yang dibutuhkan antara lain adalah modul sensor gas $\mathrm{CO}$, modul sensor gas $\mathrm{CO}_{2}$, minimum sistem ATmega 128 dan display.

\section{Board Sensor}
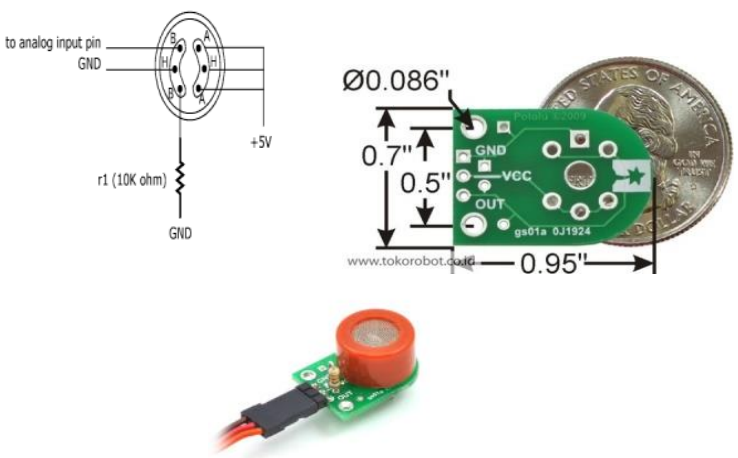

Gambar 4. a.Rangkaian konfigurasi pin, b.board sensor, c.hasil pemasangan sensor dan board 
Pada gambar 4. a diatas menununjukkan board sensor gas yang berfungsi menghubungkan kaki-kaki pada sensor terdapat 6 buah. Dimana kaki A, H, A sebelah kanan digunakan untuk input vec sebesar 5 V. Kaki B bagian atas sebagai output yang terhubung dengan ADC mikrokontroller. Kaki B bagian bawah sebagai ground dihubungkan dengan $\mathrm{R}_{\mathrm{L}}$ sebesar $10 \mathrm{k} \Omega$. Gambar $\mathrm{b}$. menunjukkan board sensor gas dimana untuk sensor MQ-7 dan MQ-135 memiliki konfigurasi pin yang sama. Sedangkan gambar c. menunjukkan sensor dan board yang telah terpasang.

\section{Minimum Sistem ATmega128}

Pada perancangan alat monitoring ini minimum sistem yang digunakan adalah ATmega 128. Minimum sistem merupakan kontroller utama pada sebuah perancangan alat monitoring yang berfungsi sebagai pusat pengolahan data sebuah sistem perangkat keras. ATmega 128 merupakan mikrokontroller AVR dengan jumlah 64 pin yang terbagi atas 7 PORT yang masing-masing memiliki 8 pin dan khusus PORT G hanya memiliki 4 pin saja. PORT F digunakan sebagai pengolah nilai ADC yang datanya berasal dari sensor kemudian port dan pin sisanya akan menjadi output data pada display, serial, dan bargraph.

Pengelamatan I/O minimum sistem pada ATmega 128 terdapat pada tabel 1. 20 pin digunakan untuk output bargraph, 2 pin digunakan untuk input sensor $\mathrm{CO}$ dan $\mathrm{CO}_{2}, 2$ pin digunakan untuk serial, dan 1 port terakhir digunakan untuk output LCD.

Tabel 1. Pengelamatan I/O Minimum Sistem

\begin{tabular}{|c|c|c|c|}
\hline \multicolumn{1}{|c|}{ No } & PORT & Fungsi & Keterangan \\
\hline 1 & PORTE.0 & Serial & Tx0 \\
\hline 2 & PORTE.1 & Serial & Rx0 \\
\hline 3 & PORTF.5 & Input & Sensor CO \\
\hline 4 & PORTF.6 & Input & Sensor $\mathrm{CO}_{2}$ \\
\hline 5 & PORTC & Output & LCD \\
\hline 6 & PORTB & Output & Bargraph \\
\hline 7 & PORTD & Output & Bargraph \\
\hline 8 & PORTE & Output & Bargraph \\
\hline
\end{tabular}

Port yang digunakan diatas terlebih dahulu dikonfiggurasi oleh code wizard pada cvAVR. Untuk tegangan input pada sensor, bargraph, LCD, dan mikrokontroller menggunakan sebuah regulator. Masing-masing tegangan input yang dibutuhkan adalah $5 \mathrm{v}$ sehingga dengan menggunakan 7805 cukup untuk mensupply keseluruhan komponen. Skematik rangkaian regulator tersebut seperti pada gambar 5 .

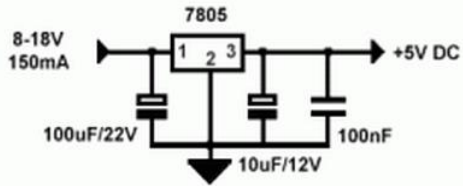

Gambar 5. Skematik Regulator

\section{Display}

Display pada sistem monitoring ini menggunakan LCD dan Bargraph. LCD digunakan untuk menunjukkan kepada pengguna proses pengolahan data secara langsung. Sedangkan bargraph digunakan untuk menunjukkan kualitas udara pada waktu tertentu. Skematik untuk LCD dan Box kualitas udara terdapat pada gambar 6 dibawah ini.

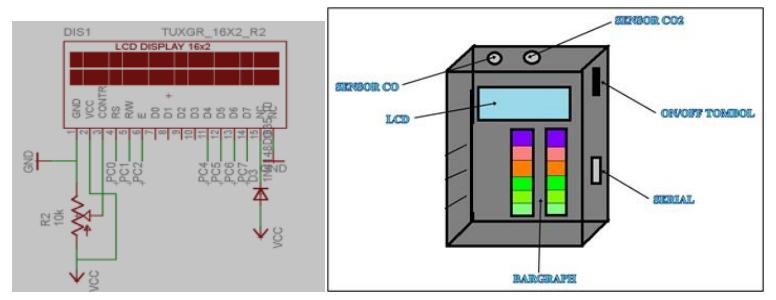

Gambar 6. a. Skematik LCD, b. Box Kualitas Udara

\section{Perancangan Perangkat Lunak}

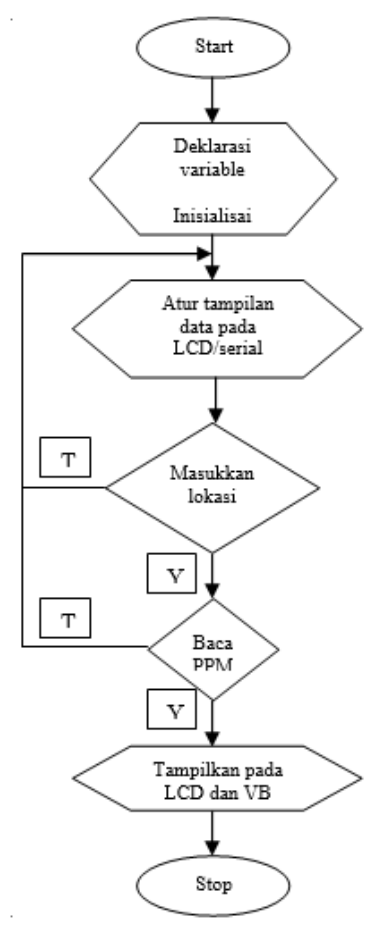

Gambar 7. Diagram Alir Perancangan Penrangkat Lunak

Pada gambar 7 diatas menunjukkan diagram alir perancangan perangkat lunak. Perancangan perangkat lunak dimulai dari proses deklarasi variable dan inisialisasi pin, setelah itu melakukan pengaturan tampilan data pada LCD sekaligus pada port serial yang outputnya pada visual basic. Pada visual basic 
sebelum dilakukan pengambilan data maka diminta untuk memasukkan lokasi titik pengambilan data, setelah terekam pada minimum sistem kemudian dilakukan pembacaan data oleh sensor. Kemudian sensor akan mengirimkan datanya pada port ADC yang telah diinisialisasi oleh minimum sistem dan menampilkan hasilnya pada LCD dan visual basic. Setelah 30 menit hasil analisa akan diperbaharui sesuai data yang telah direkam setiap 30 menit.

\section{Konfigurasi Perangkat Keras dan Perangkat Lunak}

Parsing data yang dilakukan agar dapat melakukan konfigurasi antara hardware dan software. Hal tersebut dibutuhkan beberapa perintah untuk melakukan sinkronisasi antara input pada hardware yang kemudian hasil output pada hardware tersebut menjadi input pada sistem perangkat lunaknya.

Input data dari sensor pada minimum sistem adalah berupa nilai ADC, ADC yang digunakan adalh 10 bit antara 10 - 1023 dengan menggunakan PORTF pada mikrokontroller ATmega128. Perintah pembacaan pada hardware menggunakan cvavr dengan perintah read_adc(x). Command x merupakan pin yang akan dibaca datanya oleh minimum sistem.

Pada sistem ini pertama kali sebelum melakukan pengambilan data adalah melakukan penentuan lokasi yang dilakukan oleh aplikasi yang telah dibuat. Perintah yang dilakukan untuk melakukan input lokasi disisi software terdapat pada gambar 8.a. Setelah melakukan input lokasi data dikirimkan dari aplikasi menuju hardware dengan menggunakan interrupt receiver pada UASRT0 agar dapat menyimpan lokasi pada eeprom minimum sistem. Program input pada CVAVR terdapat pada gambar 8.b.
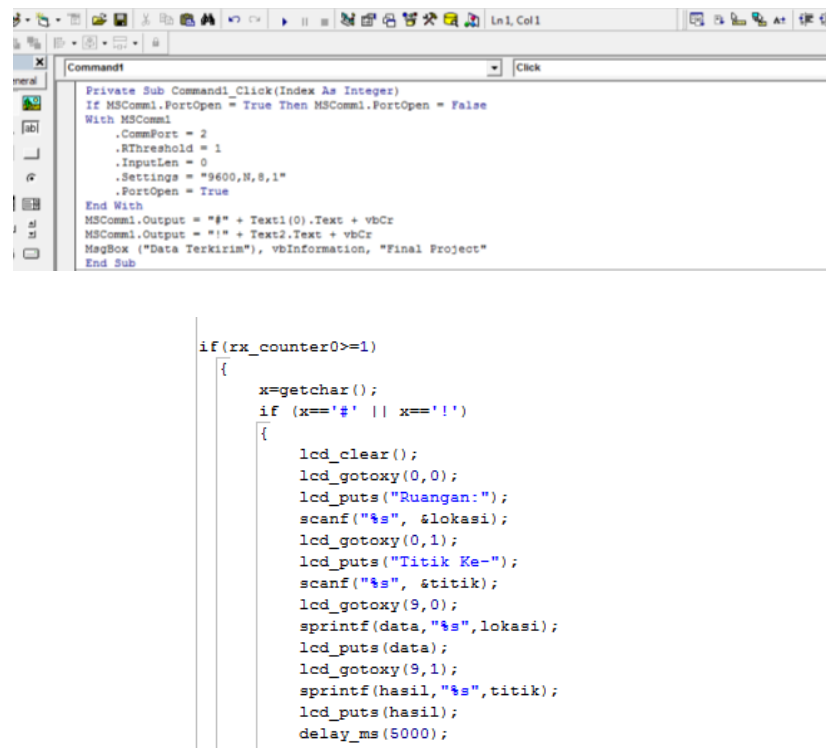

Gambar 8.a. Parsing data output pada visual basic, b. Parsing data input pada cvavr

Setelah melakukan pengambilan data alat monitoring akan melakukan analisa data, data akan diambil oleh sensor setiap menit. Data yang diterima setelah selesai diproses akan ditampilkan pada aplikasi berupa grafik yang akan terus berubah setiap menit.

Saat pengolahan data perbandingan nilai ADC dengan gas diudara didapatkan persamaan untuk masing-masing sensor yang dibaca berdasarkan nilai perbandingan Rs/Ro dari karakteristik sensor MQ-7 dan MQ-135.

Tabel 2. Perbandingan Rs/Ro pada Sensor MQ-7

\begin{tabular}{|c|c|}
\hline $\mathbf{R S} / \mathbf{R O}$ & $\mathbf{P P M}$ \\
\hline 1.8 & 200 \\
\hline 1.4 & 300 \\
\hline 1.3 & 400 \\
\hline 1.1 & 500 \\
\hline 0.95 & 600 \\
\hline 0.9 & 700 \\
\hline 0.85 & 800 \\
\hline 0.8 & 900 \\
\hline 0.78 & 1000 \\
\hline
\end{tabular}

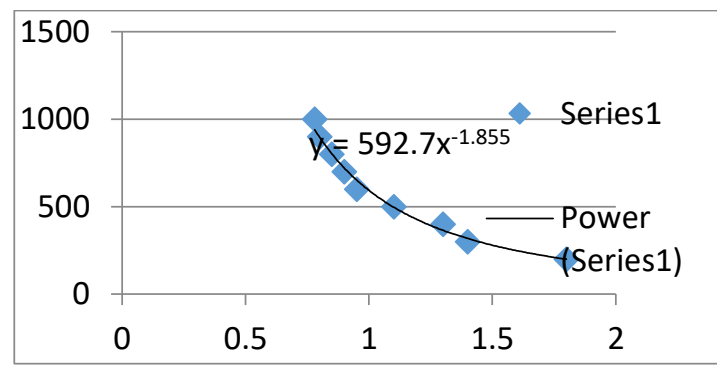

Gambar 9. Grafik persamaan sensor MQ-7

Berdasarkan persamaan diatas, nilai x kemudian diubah menjadi persamaan $\left(\frac{R s}{R o}\right)$ sehingga didapatkan persamaan akhir untuk sensor $\mathrm{CO}$ adalah:

$y C O=592,7 *\left(\frac{R s}{R o}\right)^{-1,85}$

Sedangkan untuk sensor gas $\mathrm{CO}_{2}$ nilai perbandingan dan persamaan yang didapat seperti pada tabel 3 dan gambar 10 dibawah ini.

Tabel 3. Perbandingan nilai sensor MQ-135

\begin{tabular}{|c|c|}
\hline RS/RO & PPM \\
\hline 0.8 & 200 \\
\hline 0.7 & 300 \\
\hline 0.62 & 400 \\
\hline 0.58 & 500 \\
\hline 0.55 & 600 \\
\hline 0.51 & 700 \\
\hline 0.49 & 800 \\
\hline 0.48 & 900 \\
\hline 0.46 & 1000 \\
\hline
\end{tabular}

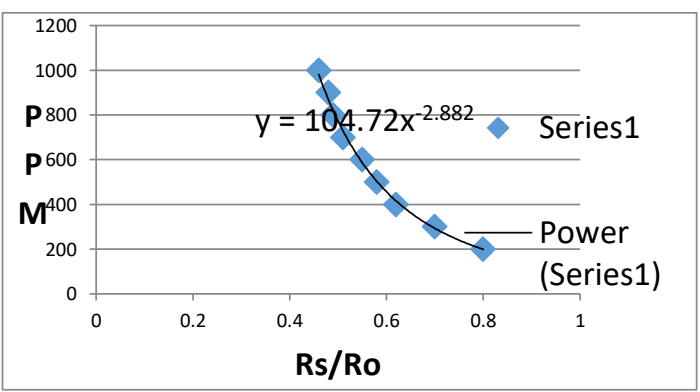

Gambar 10. Grafik persamaan sensor MQ-135 
Nilai x dari persamaan diatas kemudian diubah menjadi $\left(\frac{R s}{R o}\right)$, sehingga persamaan akhir untuk sensor gas $\mathrm{CO}_{2}$ adalah sebagai berikut:

$$
y C O_{2}=104,7 *\left(\frac{R s}{R o}\right)^{-2,88}
$$

Dari persamaan (1) dan (2) nilai $R_{S}$ merupakan hasil dari persamaan (3) dibawah ini:

$R_{S}=\left(\frac{V c-V R l}{V R l}\right) * 10000$

Setelah selesai menentukan standar perhitungan pada sensor sesuai dengan karakteristik masing - masing sensor data yang diterima kemudian dilakukan analisis deskriptif. Analisis deskriptif yang dilakukan agar suatu kumpulan data dapat mudah dipahami karakteristiknya. 10 analisis deksriptif dilakukan anatara lain adalah menentukan:

a. Max

Nilai maksimum digunakan untuk menentukan nilai tertinggi dari suatu data sehingga dapat dideteksi apabila melebihi batas bahaya

b. Min

Nilai minimum digunakan untuk menentukan nilai terendah dari suatu kumpulan data

c. Mean

Nilai mean adalah nilai rata-rata $(\bar{x})$ dari seluruh data. Hasil mean ini didapatkan dari persamaan:

$\bar{x}=\frac{x_{1}+x_{2}+\ldots+x_{n}}{n}$

d. Modus

Modus adalah nilai yang paling banyak keluar pada kumpulan data tersebut modus didapat dari dari persamaan berikut ini :

$M o=b+p\left\{\frac{b_{1}}{b_{1}+b_{2}}\right\}$

e. Median

Median adalah nilai tengah suatu data setelah disusun menurut urutan nilainya. Jika nilai $\mathrm{n}$ ganjil maka nilai median (Me) adalah nilai paling tengah sedangkan bila nilai $\mathrm{n}$ berjumlah genap maka median (Me) akan bernilai ratarata dari dua hitung data tengah. Median sendiri dapat dihitung dengan menggunakan persamaan:

$$
\text { Me }=b+p\left\{\frac{n / 2-F}{f}\right\}
$$

f. Range

Range merupakan jarak antara nilai maksimum yang dikurangi dengan nilai minimum.

g. Standar Deviasi

Standart deviasi merupakan ukuran dari seberapa luas simpangan nilai dari rata-rata(mean). Standart deviasi sendiri dapat dihitung menggunakan persamaan:

$\mathrm{s}=\sqrt{\frac{\sum_{i=1}^{n}\left(x_{i}-\bar{x}\right)^{2}}{n-1}}$

h. Varians
Varians merupakan nilai kuadrat dari simpangan baku (standart deviasi) sehinggan nilai varians didapat dari hasil $\mathrm{s}^{2}$

i. Skewness

Jika kurva frekuensi suatu distribusi memiliki ekor yang lebih memanjang ke kanan (dilihat dari mean) maka dikatakan positif dan apabila menceng kekiri maka akan bernilai negative. Secara perhitungan, skewness adalah momen ketiga terhadap mean. Distribusi normal memiliki nilai skewness 0 . Nilai skewness sendiri dapat dihasilkan melalui persamaan :

Skewness $=\frac{1}{n S^{3}} \sum_{i=1}^{n}\left(x_{i}-\bar{x}\right)^{3}$

j. Kurtosis

Kurtosis adalah derajat keruncingan suatu distribusi. Kurva yang lebih runcing dari distribusi normal dinamakan leptokurtik, yang lebih datar platikurtik dan distribusi normal disebut mesokurtik. Kurtosis dihitung dari momen keempat terhadap mean. Distribusi normal memiliki nilai kurtosis $=3$, sementara yang leptokurtic biasanya kurtosisnya $>3$ dan platikurtik $<3$. Nilai kurtosis sendiri dapat didapatkan dari persamaan:

$\kappa=\frac{S K}{P_{90}-P_{10}}=\frac{0.5\left(K_{3}-K_{1}\right)}{P_{90}-P_{10}}$

Selain menggunakan analisis deskriptif, analisis yang digunakan histogram yang digunakan untuk mengetahui distribusi data yang telah dikumpulkan

\section{HASIL DAN ANALISA}

Pengujian dan pengambilan data dilakukan di Rumah Sakit Haji, Sukolilo Surabaya. Dilakukan sebanyak 3 lokasi antara lain pada kamar pasien, ruang parkir rumah sakit, dan ruang tunggu rumah sakit.

\section{Pengujian pada Kamar Pasien Rumah Sakit}

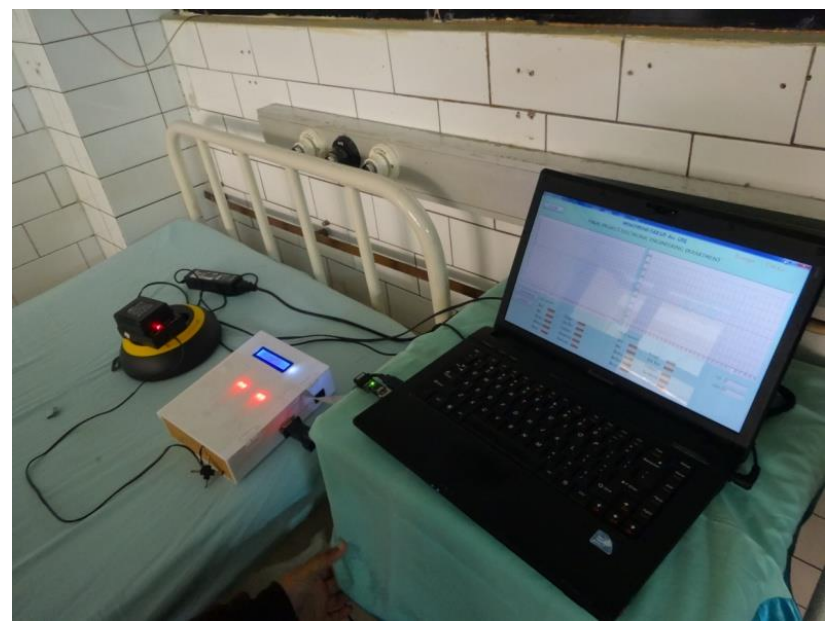

Gambar 11. Dokumentasi saat pengambilan data dikamar pasien

Gambar 11 diatas menunjukkan dokumentasi saat melakukan pengambilan data pada kamar pasien rumah sakit. Dari hasil 
pengambilan data tersebut didapatkan nilai rata-rata selama 26 menit pengukuruan adalah hasil kadar gas $\mathrm{CO}$ sebesar 1,74 ppm dan kadar $\mathrm{CO}_{2}$ sebesar $124,81 \mathrm{ppm}$. Apabila dikorelasikan dengan hasil indeks kadar gas berbahaya dalam rumah sakit peraturan kepmenkes dan hasil nilai persamaan berdasarkan karakteristik dan kalibrasi maka didapatkan hasil pengukuran pada kamar pasien dalam keadaan baik.

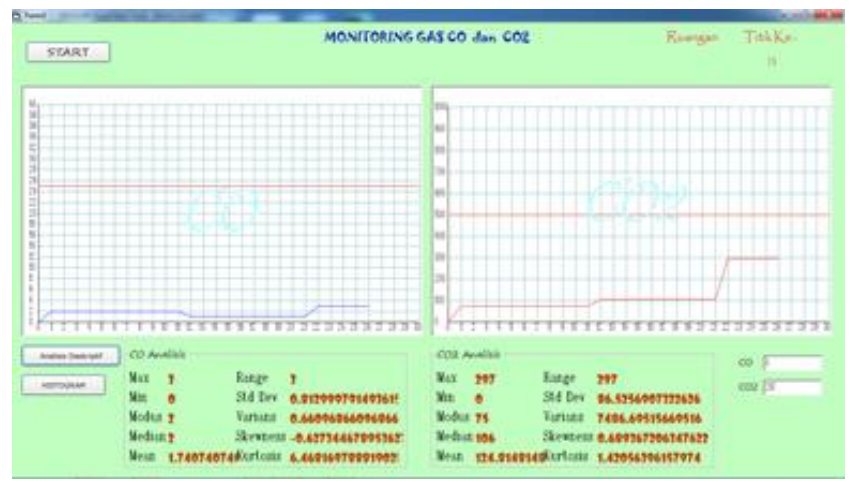

Gambar 12. Hasil pengujian pada kamar pasien rumah sakit

Analisis dengan menggunakan histogram pada kamar pasien rumah sakit terlihat pada gambar 13 dan 14. Dan secara rinci data dapat dilihat pada tabel 4 dibawah ini.

Tabel 4. Tabel histogram data pada kamar pasien

\begin{tabular}{|c|c|c|c|}
\hline Kelas & CO & Kelas & CO2 \\
\hline $0-0.25$ & 1 & $0-24.75$ & 1 \\
\hline $0.25-0.5$ & 0 & $24.75-49.5$ & 0 \\
\hline $0.5-0.75$ & 0 & $49.5-74.25$ & 0 \\
\hline $0.75-1$ & 0 & $74.25-99$ & 0 \\
\hline $1-1.25$ & 10 & $99-123.75$ & 11 \\
\hline $1.25-1.5$ & 0 & $123.75-148.5$ & 10 \\
\hline $1.5-1.75$ & 0 & $148.5-173.25$ & 0 \\
\hline $1.75-2$ & 0 & $173.25-198$ & 0 \\
\hline $2-2.25$ & 11 & $198-222.75$ & 0 \\
\hline $2.25-2.5$ & 0 & $222.75-247.5$ & 0 \\
\hline $2.5-2.75$ & 0 & $247.5-272.25$ & 0 \\
\hline 2.75 & 0 & 272.25 & 0 \\
\hline
\end{tabular}

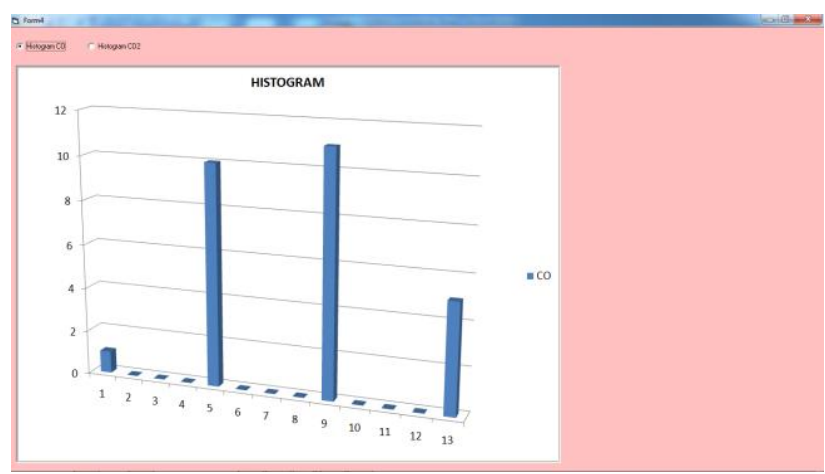

Gambar 13. Grafik hasil analisis histogram CO kamar pasien

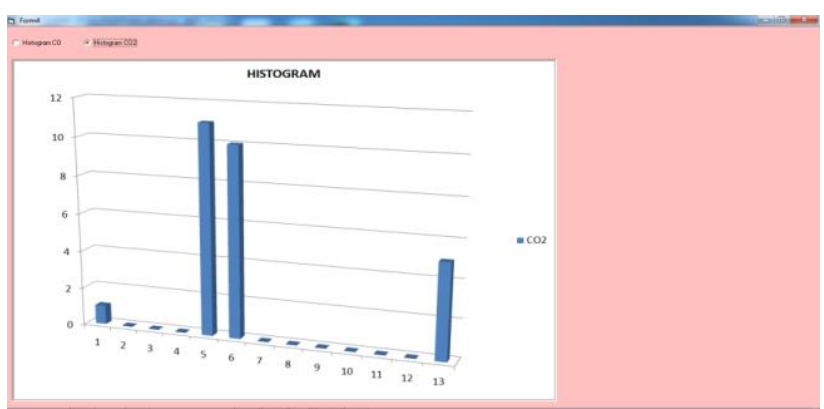

Gambar 14. Grafik hasil analisis histogram $\mathrm{CO}_{2}$ pada kamar pasien

\section{Pengujian pada Ruang Parkir Rumah Sakit}

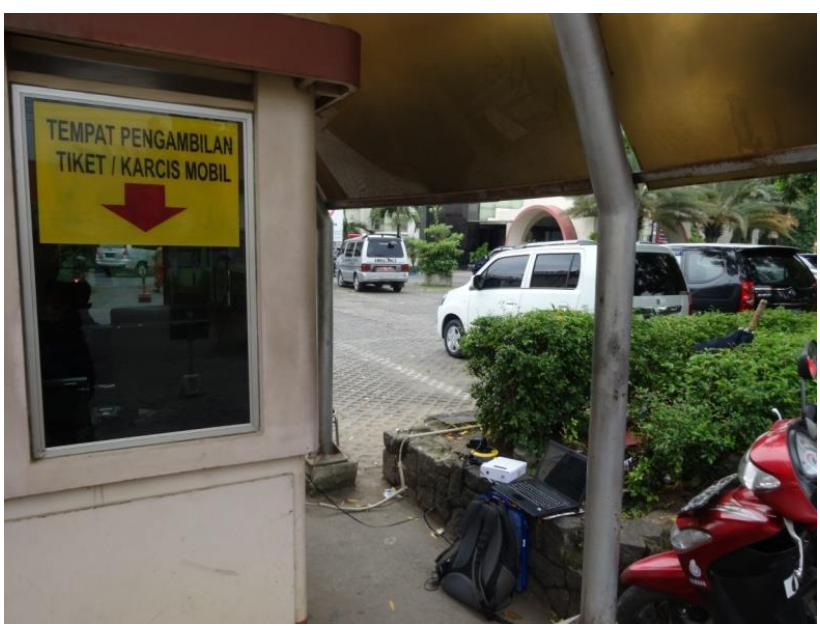

Gambar 15. Dokumentasi pengambilan data pada area parkir

Gambar 15 diatas menunjukkan dokumentasi saat melakukan pengambilan data pada area parkir rumah sakit. Dari hasil pengambilan data tersebut didapatkan nilai rata-rata selama 179 menit pengukuruan adalah hasil kadar gas CO sebesar 17,19 ppm dan kadar $\mathrm{CO}_{2}$ sebesar $687,80 \mathrm{ppm}$. Apabila dikorelasikan dengan hasil indeks kadar gas berbahaya dalam rumah sakit peraturan kepmenkes dan hasil nilai persamaan berdasarkan karakteristik dan kalibrasi maka didapatkan hasil pengukuran pada area parkir dalam keadaan tidak baik.

Gambar 16 dibawah ini akan menunjukkan grafik pada saat pengambilan data selama 179 menit dan dapat dilihat bahwa kadar $\mathrm{CO}_{2}$ telah melibihi batas aman. Area parkir merupakan area yang banyak dilakukan lalu lalang kendaraan bermotor sehingga area tersebut memang sudah wajar bila tidak memiliki lingkungan yang baik. Tujuan pengambilan data pada area parkir ini adalah untuk menunjukkan perbedaan yang signifikan antara satu ruangan dengan ruangan yang lainnya.

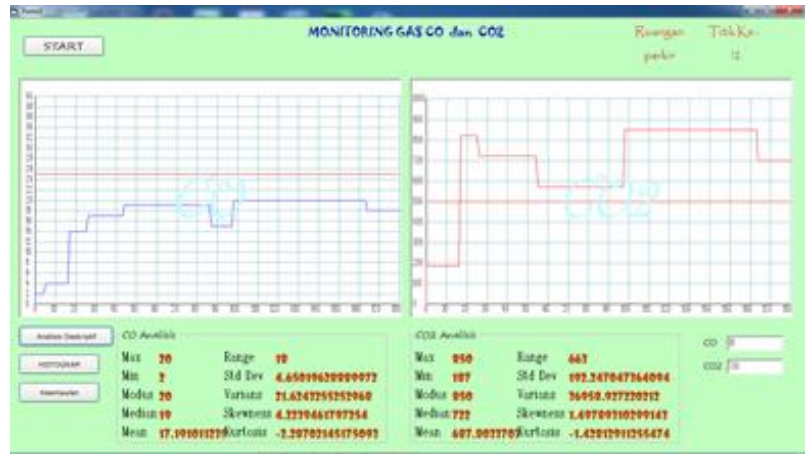


Gambar 16. Hasil pengujian pada area parkir rumah sakit

Dari hasil pengujian data diatas didapatkan pengelompokkan data untuk melakukan analisis histogram pada tabel 5 dibawah ini.

Tabel 5. Tabel histogram pada data area parkir rumah sakit

\begin{tabular}{|c|c|c|c|}
\hline Kelas & CO & Kelas & CO2 \\
\hline $0-1.5$ & 0 & $0-55.25$ & 0 \\
\hline $1.5-3$ & 0 & $55.25-110.5$ & 0 \\
\hline $3-4.5$ & 5 & $110.5-165.75$ & 0 \\
\hline $4.5-6$ & 12 & $165.75-221$ & 0 \\
\hline $6-7.5$ & 0 & $221-276.25$ & 17 \\
\hline $7.5-9$ & 0 & $276.25-331.5$ & 0 \\
\hline $9-10.5$ & 0 & $331.5-386.75$ & 0 \\
\hline $10.5-12$ & 0 & $386.75-442$ & 0 \\
\hline $12-13.5$ & 0 & $442-497.25$ & 0 \\
\hline $13.5-15$ & 0 & $497.25-552.5$ & 0 \\
\hline $15-16.5$ & 20 & $552.5-607.75$ & 0 \\
\hline 16.5 & 0 & 607.75 & 43 \\
\hline
\end{tabular}

Kesimpulan yang didapatkan dari hasil pengujian selama 179 menit tersebut dapat ditampilkan pada gambar 17 dibawah ini.

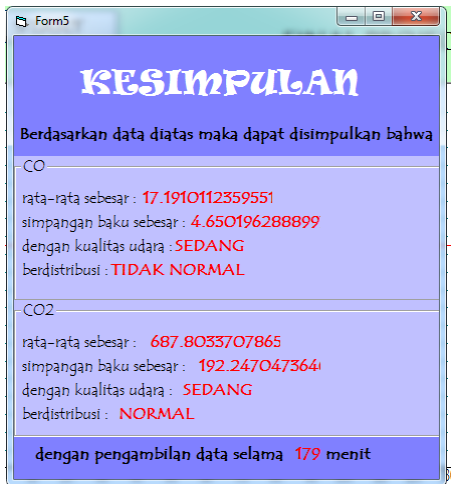

Gambar 17. Hasil kesimpulan pada pengambilan data area parkir rumah sakit

\section{Pengujian pada Ruang Tunggu Rumah Sakit}

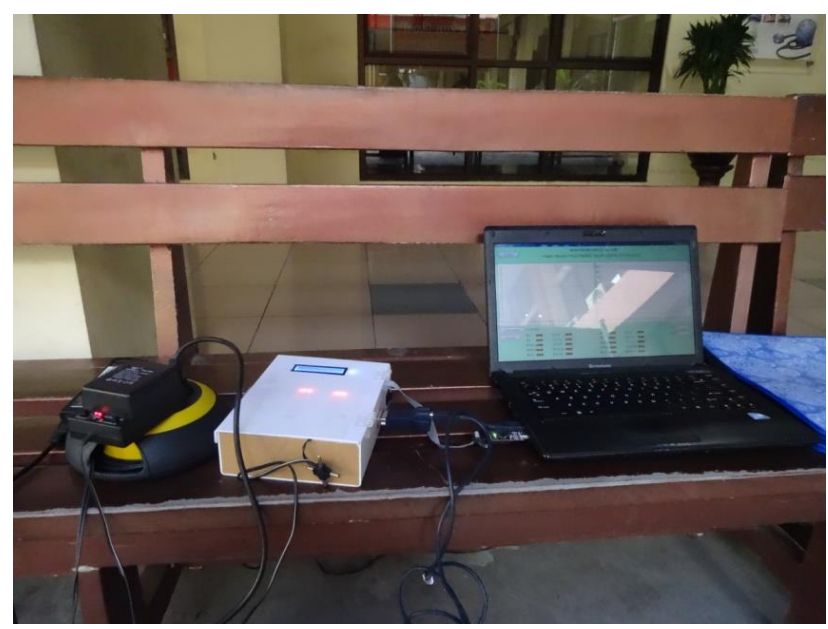

Gambar 18. Dokumentasi saat pengambilan data pada ruang tunggu

Gambar 18 diatas menunjukkan dokumentasi saat melakukan pengambilan data pada ruang tunggu rumah sakiy. Dari hasil pengambilan data tersebut didapatkan nilai rata-rata selama 179 menit pengukuruan adalah hasil kadar gas $\mathrm{CO}$ sebesar 3,62 ppm dan kadar $\mathrm{CO}_{2}$ sebesar 576,27 ppm. Apabila dikorelasikan dengan hasil indeks kadar gas berbahaya dalam rumah sakit peraturan kepmenkes dan hasil nilai persamaan berdasarkan karakteristik dan kalibrasi maka didapatkan hasil pengukuran pada ruang tunggu adalah baik untuk kadar $\mathrm{CO}$ dan waspada untuk kadar gas $\mathrm{CO}_{2}$.

Gambar 19 dibawah ini akan menunjukkan grafik pada saat pengambilan data selama 179 menit dan dapat dilihat bahwa kadar $\mathrm{CO}_{2}$ telah melibihi batas aman dalam beberapa kondisi tertentu. Ruang tunggu yang belum $100 \%$ steril dari asap atau pembakaran karena ruangan bersiap semi oudoor menyebabkan gas $\mathrm{CO}_{2}$ memiliki kadar yang lebih tinggi bahkan melebihi batas normal walaupun tidak dalam keadaan berbahaya seperti pada keadaan area parkir. Hal tesebut dapat menjadi kewaspadaan pada pasien yang memiliki gangguan pernapasan untuk tidak lamalama dibiarkan diruang tunggu rumah sakit.

Pengelompokkan data yang didapatkan dari hasil pengukuruan selama 179 menit dirumah sakit dapat terlihat pada tabel 6 . Sedangkan hasil kesimpulan dapat terlihat pada gambar 20.

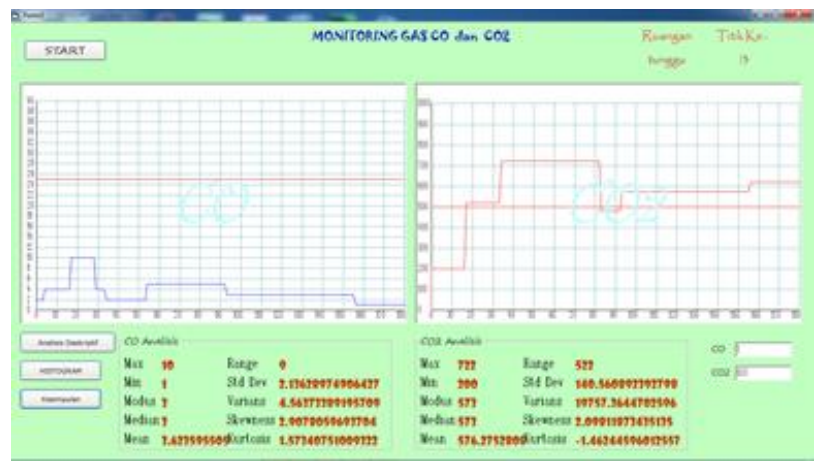

Gambar 19. Hasil pengujian pada area ruang tunggu rumah sakit

Tabel 6. Tabel histogram pada ruang tunggu rumah sakit

\begin{tabular}{|c|c|c|c|}
\hline Kelas & CO & Kelas & CO2 \\
\hline $0-0.75$ & 0 & $0-43.5$ & 0 \\
\hline $0.75-1.5$ & 0 & $43.5-87$ & 0 \\
\hline $1.5-2.25$ & 31 & $87-130.5$ & 0 \\
\hline $2.25-3$ & 24 & $130.5-174$ & 0 \\
\hline $3-3.75$ & 63 & $174-217.5$ & 0 \\
\hline $3.75-4.5$ & 0 & $217.5-261$ & 17 \\
\hline $4.5-5.25$ & 18 & $261-304.5$ & 0 \\
\hline $5.25-6$ & 39 & $304.5-348$ & 0 \\
\hline $6-6.75$ & 0 & $348-391.5$ & 0 \\
\hline $6.75-7.5$ & 0 & $391.5-435$ & 0 \\
\hline $7.5-8.25$ & 0 & $435-478.5$ & 0 \\
\hline 8.25 & 0 & 478.5 & 0 \\
\hline
\end{tabular}




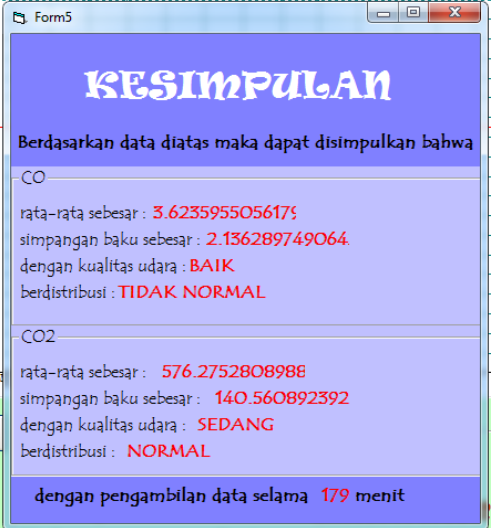

Gambar 20. Hasil kesimpulan pada ruang tunggu rumah sakit

Hasil kesimpulan tersebut didapatkan berdasarkan analisa deskriptif yang diambil dari hasil rata-rata kadar gas dalam udara. Nilai simpangan baku yang tinggi atau tidak berdasarkan hasil perhitungan s/ $\overline{\mathrm{X}}$.

\section{KESIMPULAN}

Dari keseluruhan tahapan penyelesaian sistem ini dapat disimpulkan bahwa:

1. Hasil kalibrasi alat menunjukkan error pada sensor gas $\mathrm{CO}$ adalah $15,11 \%$ dan untuk sensor gas $\mathrm{CO}_{2}$ adalah sebesar $24,08 \%$ dari hasil tersebut menunjukkan sensor $\mathrm{CO}_{2}$ memiliki akurasi yang rendah. Dari hasil tersebut sensor yang sebarusnya digunakan adalah sensor yang fokus untuk pendeteksian gas $\mathrm{CO}_{2}$ saja agar memiliki akurasi yang lebih tinggi seperti pada sensor gas $\mathrm{CO}$.

2. Hasil pengujian berupa output pada aplikasi menunjukkan error rata-rata sebesar $2,3 \%$ hal tersebut dikarenakan mikrokontroller mengalami masalah saat melakukan pengiriman data melalui serial. Namun data tersebut masih tersimpan pada memory.

\section{UCAPAN TERIMA KASIH}

Ucapan terima kasih diberikan kepada laboratorium kalibrasi UPTK3 Surabaya, Rumah Sakit Haji Surabaya, dan rekan-rekan ITTelkom Surabaya

\section{REFERENSI}

[1] A. H. S. S. I. Windi Wulandari, "Angka Kuman Udara dan Lantai Ruang Ramah Inap Rumah Sakit PKU Muhammadiyah Yogyakarta," Jurnal Berkala Kesehatan, pp. 13 - 20, 2015.

[2] M. K. R. Indonesia, "Keputusan Menteri Kesehatan Republik Indonesia Nomor 1204/MENKES/SK/X/2004," Menteri Kesehatan Republik Indonesia, 2004.

[3] S. M. E. B. Lisa Jayanti, "Kesehatan Lingkungan Udara Ruang Rawat Inap Rumah Sakit Syekh Yusuf Kabupaten Gowa," HIEGENE, pp. 33-40, 2016.

[4] E. Wulandari, "FAKTOR YANG BERHUBUNGAN DENGAN KEBERADAAN STREPTOCOCCUS DI UDARA PADA RUMAH SUSUN KELURAHAN
BANDARHARJO KOTA SEMARANG TAHUN 2013," Unnes Journal of Public Health, pp. 1-9, 2013.

[5] M. C. B. P. L. B. d. Jonathan A. Bernstein, "Health effects of air pollution," Environmental and occupational respiratory disorders, pp. $1116-1123,2004$. 